\title{
Human Capital and Intellectual Capital in Modern International Business \\ - Based on Studies of the Strategies of Transnational Corporations
}

\author{
Magdalena Rosińska-Bukowska \\ Ph.D., Associate Professor University of Lodz, Faculty of Economics and Sociology \\ International Business and Trade Department, Lodz, Poland \\ e-mail: magdalena.rosinska@uni.lodz.pl
}

\begin{abstract}
The main objective of the article is to discuss the direction of changes in the strategies of the most powerful transnational corporations as a result of adjustments to the new challenges created by the growing role of human capital in contemporary international business. Based on the concept of Grounded Theory Methodology, the author will indicate the main pillars of the strategy which can be considered effective for new challenges. The study has been divided into three parts. The first part discusses the most important theoretical issues concerning the place of human capital in the strategies of contemporary enterprises. In the second part, the author characterizes new trends in international transfers of human capital. In the next part, based on the research, the author discusses the impact of changes on the organizational and management system of enterprises - on the example of the most powerful transnational corporations. The studies have shown that all the most powerful transnational corporations notice the growing role of intellectual capital in contemporary business. The basis of corporations' strategies is the emphasis put on the development of subsystems of intellectual capital, which refers to the activation of international transfers of human capital. In consequence, the strategies of the development of the most powerful transnational corporations are based on three pillars: networking, orchestration, and coopetition, and they are based on the three subsystems of intellectual capital: organizational capital, innovations, and the institutional environment.
\end{abstract}

Keywords: human capital; intellectual capital; transnational corporations; international business

JEL: F23, J24, M16, O30, O34 


\section{Introduction}

The global economy is changing dynamically, mainly due to the increase in the importance of intellectual capital (IC) as a driving force for development. The challenge for modern businesses is to find ways to permanently explore all layers/subsystems of the intellectual capital of organizations. For this purpose, it is necessary to identify IC subsystems, the elements which constitute its individual layers, and the forces which act as accelerators for each of them. It is also crucial to highlight the special role of human capital (HC) in modern business, including the recognition of the potential of international corporate transfers (ICTs) of HC.

The most powerful transnational corporations (Top-TNCs) seem to use the potential of IC effectively, developing their global business networks (GBNs) and becoming aware of a change in the role of HC in international business. Therefore, the study, based on studies of the Top-TNCs, attempts to indicate the desired directions of changes in the strategies of enterprises which enable the effective long-term meeting of new challenges.

The research involved business models of corporations that are the leaders of particular industry sectors in terms of their ability to adapt to the growing role of IC and relating the study of international corporate transfers (ICTs) to that role. A key challenge which was identified was to find methods for the effective transfer of knowledge, skills and competencies of employees located in various parts of the company around the world, in such a way as to build the company's IC which is capable of multiplying its economic capital. Therefore, an attempt was made to check the extent to which the Top-TNCs (of various sectors) are prepared to meet the requirements of networking, orchestration and coopetition as fundamental principles for the development of a modern international business.

The analytical model is based on the assumption that changes in the global economy have forced changes in enterprises based on the intensification of cooperation on many levels and in various fields, and the constant development of international entrepreneurship and global network structures. The study assumed that improving competitiveness is an effect of the ability to constantly create added value by exploring the multi-layered capital of the global corporate network that takes advantage of the growing role of human capital.

The proposed approach pays special attention to the necessity to explore the potential of the global environment through the use of international transfers of human capital. Additionally, the author emphasizes the role of knowledge, competence, skills, innovation and entrepreneurship (the theory of key competencies, the theory of innovation, the concept of international entrepreneurship, behavioral concepts). The concept is an attempt to present a model for the creation of the competitiveness of TNCs through the combination of positional and resource streams and taking into account the importance of the international context. It requires an interdisciplinary analytical approach, the triangulation of research methods and the use of a combination 
of concepts of internationalization, strategic management, human capital management, migration, entrepreneurship, innovation, and sustainable development (Rosińska-Bukowska 2017; Hagen, Denicolai, Zucchella 2014; Saxenian 2006; Massey 2005). Additionally, it was shown that the ability to build appropriate relationships and structures (organization and management theories, agglomeration theories, mergers and acquisitions) based on the specificity of the resource that is $\mathrm{HC}$ is of particular importance for the efficiency of the organizational and managerial model of TNCs.

The main objective of the article is to discuss the direction of changes in the strategies of Top-TNCs as s result of the adjustments to the challenges created by the growing role of IC and the special position of $\mathrm{HC}$ in contemporary international business. The additional purpose, based on the concept of Grounded Theory Methodology (GTM), is to determine the main pillars of the strategies which enable enterprises to meet new challenges effectively.

The study has been divided into three parts. The first part discusses the most important theoretical issues concerning the position of intellectual and human capitals in the strategies of contemporary enterprises. In the second part, the author characterizes trends in international transfers of human capital. In the following part, the author discusses, on the basis of the research, the impact of changes on the organizational and management system of enterprises - based on the example of Top-TNCs. This section discusses the methodological assumptions of the empirical studies, including the research design, the description of the analysis diagram, the rules for the selection of objects, the empirical results of the survey and suggestions for further studies.

\section{The Importance of Intellectual Capital and the Position of Human Capital in the Strategies of Modern Enterprises}

The growing role of IC as the driving force of modern business means that the accumulation of knowledge and experience among the members of the business system is faster - the ICTs of HC plays an important role in this process. The author refers primarily to the following concepts: intellectual capital and human capital (the management theory); migration (the international transfer of production factors); the concept of accumulating and implementing knowledge (the behavioural theory of the firm); and the concept of international entrepreneurship (the interdisciplinary theory of the firm). The author has explained the classical competitive perspective of internationalization as an incremental process, using the learning concepts based on the cooperation with the internal and external environments in global economy (Rosińska-Bukowska 2017; Vahlne, Ivarsson 2014; McDougall-Covin, Jones, Serapio 2014; Coviello, Jones, McDougall-Covin 2014; Zucchella, Sciabini 2007).

The concept of IC and the place of HC in the enterprise system have been long discussed in the literature of the subject (Stahle, Stahle, Aho 2011; Choong 2008, pp. 609-693; Wall, Kirk, Martin 2004; Stewart 2001; Petty, Guthrie 2000, pp. 155-176). 
Many researchers use the terms "human capital" (HC) and "intellectual capital" (IC) interchangeably. This approach, however, seems to be a simplification. IC includes (Klaila 2000): knowledge, skills, creativity, the experience of HC (human assets); all material and intangible effects of this capital (including patents, copyrights, publications, etc.); behavioral models such as the organizational culture, processes, procedures, communication and distribution channels (structural assets) and the brand, reputation, relationship with the environment, and goodwill (intangible assets). Therefore, IC is a wider and much more complete concept. It seems appropriate to enumerate its three subsystems (Rosińska-Bukowska 2012, pp. 97-112): organizational capital (ORGC), innovative capital (INNC) and institutional capital (INSC), which are linked through the activity and creativity of HC. Although people create knowledge, it is only through interactions between them that its scope is increased, and, as a result, the institutionalized knowledge of a given organization, its intellectual capital, is created. IC is a quasi-public good (standards, customs, patterns), recognized in a given organization as a standard whose dissemination among its members allows it to raise the effectiveness of the system as a whole. In this approach, IC can be identified with the corporate culture of the organization.

Emphasizing the key role of HC in modern business is, of course, right (Stahle, Stahle Aho 2011; Stewart 2001; Bontis 2001; Ross, Ross 1997). HC is the foundation of IC, which, in turn, is a multiplier of accumulated economic capital (AEC). HC permeates all three subsystems of IC, and it triggers the potential inherent in them. HC connects the business system by shaping a specific organizational management model through:

- structures - internal and external (organized to serve the transfer of knowledge, not purely transactional, flattened; based on building a sequence of the processes of value creation; subjected to systematic reorganization to the rhythm of observed changes);

- innovations - product-related, process-related and organizational (constantly and quickly implemented for specific segments/modules, competently coordinated in the system);

- institutions - principles of building relationships with a diverse internal and external environment (through the intensification of various forms of cooperation, the creation of socio-economic values, socially responsible activities).

A contemporary model of strategic management, based on a system-situational approach, emphasizes the role of knowledge resources (Brennan, Connel 2000, pp. 206240), which are present on many levels in a given organization's relationships. IC influences the efficiency of the exploration (not exploitation) of AEC in the organization. In the modern international business, the network of organizational, pro-innovative and institutional relations, built thanks to the creativity of human capital, is the basis of the ability to create socio-economic values (Andelin, Karhu, Junnila 2015, pp. 446453). Modern business requires the creation of collective, institutional knowledge (Sarvary 1999, p. 95), based on the junction effect, joining the processes of creation, accu- 
mulation, organization, dissemination, implementation and exploration of knowledge (Skyrme 1999, p. 59). The necessary condition for the development of a modern enterprise is, therefore, the ability to orchestrate multilevel cooperation even with existing competitors - coopetition and distinguishing the skills of effective value creation on the basis of diversified resources of many entities (Dhanaraj, Parkhe 2006, pp. 659669). From the perspective of these considerations, it is crucial to draw attention to the role of HC in a corporation's management system. First of all, it is based on the perception of the necessity to build a long-term advantage based on the manager's ideas. Secondly, it involves making full use of all available categories of human resources as carriers of knowledge, skills and competencies. A contemporary TNC is an entangled organization, working as a system of joined vessels, combining competition and cooperation as well as the market and hierarchy (Rosińska-Bukowska 2012; Håkansson, Snehota 1995). Researchers have provided evidence of how different factors facilitate or constrain the success of individual companies. Generally, different researchers focus on their preferred approaches, e.g., the role of IC (Sveiby 2015; McCutcheon 2008, pp. 79-96; Bounfour 2003, pp. 396-413) or the role of entrepreneurship in the context of internationalization and globalization (Wach 2015). According to the author of this article, it would be preferable to create a holistic approach to management and development strategies in contemporary international business (as demonstrated by, for example, Pike, Rylander, Roos 2001; Viedma 2001, pp. 148-164). The strategy of TNCs in this text is presented from the evolutionary perspective - as an adjustment to the global changes. The state of balance is a moment in which a company and its system (business network) are optimally incorporated into the requirements of the environment (Hodgson, Knudsen 2006, pp. 477-489). In conclusion, the key guidelines for the management systems based on IC that intend to explore the possibilities of a growing international transfer of human capital are:

- networking - a strategy of pro-development openness, systematic development of a network of diverse types of relations (ORGC),

- orchestration - sharing knowledge, managing the knowledge capital accumulated in the system on many levels, in order to constantly create new solutions (INNC),

- coopetition - the ability to combine cooperation and competition based on the idea of sustainable development (INSC).

The indicated elements are of fundamental importance in the contemporary model of international business and should be the pillars of a development strategy as they make it possible to face new challenges. 


\section{International Transfers of Human Capital - Implications for International Business}

The changes, both technological and organizational, occurring in the global economy contribute to the increase in mobility of the factors of production, including HC. As a result, the structure of human resources on the global market also changes. The importance of the skillful use of the international mobility of employees and functioning in a transnational environment continue to increase in modern companies. One of the key matters is building multinational teams which consist of employees from various parts of the world. By analyzing the ICTs of $\mathrm{HC}$, it is possible to observe their increasing influence on the functioning of modern enterprises. Currently, the rates of self-initiated expatriates participating in a general migrant population continue to increase. The continually growing migration of well-educated people is a relatively new phenomenon. If the enterprises on the national market are not able to absorb these resources, or their offers are unsatisfactory, the employees migrate, searching for jobs in other countries and thus making up the group of expatriates.

TNCs are enterprises which organize production on a global level, recruit professionals all over the world and send them to countries outside of their country of birth or education. By founding other branch offices, they send them away from their mother companies (D'Costa 2006, p. 8) or other units in their global structure. The transfer of human resources occurs within an internal structure (of a single corporation) or a global network - a system of companies connected to each other (often informally). The increase in migration and expatriation contributes to the evolution of organizational structures of the Top-TNCs. Studies (of 143 TNCs) show that a great majority of TNCs - 74\% - confirm that the international transfer of personnel (both long- and short-term) is permanent, and $43 \%$ additionally declare that the number of their international personnel will continue to grow (Global Mobility, 2015). The reason is their search for young and talented managers and including them in the global structures of business networks. At the same time, highly-qualified employees are especially inclined to international mobility. This is the result of, among other things, the need to raise qualifications via the exchange of experience (delegated personnel) or the search for a higher quality of life by selling services abroad (expatriates). Staying in a branch office abroad may involve the introduction of new technologies and/or using local determinants to create further innovations (INNC); building the structures of an organizational system (ORGC); auditing and coordinating the work of the local team in accordance with the model of a given TNC; and identifying problems and determining the methods of solving them, while taking into account the priorities of the organizational culture of the mother corporation (INSC). The ICTs can be divided according to the functions fulfilled by the person delegated in the organizational structure (Coorens 2013; Dowling, Festing, Engle 2013; Reiche 2009; Harzing 2001).

The contemporary position of an organization is, to a greater and greater degree, a reflection of the quality of its intellectual capital, which is based on human capital (in- 
cluding migrants and expatriates). The change in the models of business corporations, the dynamics of technological changes and the constant pressure to cut costs forced by the competition result in the international short- and long-term transfer of human resources being both permanent and continually increasing. The key challenge is to use human capital as an accelerator of the potential in each subsystem of the organization's intellectual capital. It is recommended that the management identify the pillars of the development strategy, which will make it possible to attain cohesion in the aims of individual migrants and long-term aims of the organization since only this will enable the transfer of knowledge, skills, and competencies of individual people/expatriates to the intellectual capital. In a contemporary enterprise, people are the most precious assets. While other assets may undergo depreciation, people have the ability to quickly raise their value by learning. They can contribute to the creation of added value, raising competitiveness and increasing the enterprise's innovativeness more than other resources. Expatriates fulfill a crucial role and are considered technological and organizational transfer belts of know-how from the mother corporation. They are the transfer facilitators. They are boundary spanners between various systems and cultures. They are often the effective vehicles enabling transfer since they participate in the destruction of barriers and the production of energy from existing differences. That is why this aspect is so crucial and needs to be included in further studies.

\section{The Significance of Human Capital in Management Systems of Transnational Corporations. The Analysis of Empirical Studies}

The management process is a system of relationships between an enterprise's aims and the strategies of achieving them, as well as its organizational structures and culture. Changes in the economy result in the restructuring of the management systems of enterprises so as to enable them to use the diversity potential to the fullest. It is possible only thanks to human capital, which activates individual layers of the intellectual capital of a given organization. Consequently, the key qualities of a contemporary advanced business model include:

- networking (building a spider's web-like system of multi-level correlations to improve effectiveness - proprietary, strategic and cooperative connections); the development of the organizational IC subsystem (ORGC);

- orchestration (combining standards with the specificity of local cultures and competencies of multinational human capital to create added value, including socially-useful innovative values (Andelin, Karhu, Junnila 2015, pp. 446-453); the appreciation of the social capital of local spaces; replacing hierarchical management with the regulatory model); the development of an innovative IC subsystem (INNC); 
- coopetition (the constant combination of competition and cooperation involving the appreciation of all stakeholders and the creation of value added to the constantly growing standard as a result of internal interactions within a GBN) the development of an institutional IC subsystem (INSC).

In this article, the degree to which these challenges are reflected in the business practices of the greatest enterprises (transnational corporations, the leaders of their industry sectors) is of great importance. In order to analyze this matter, attention should be paid to the role of IC and the determinants of development strategies (pillars of the organizational culture of a given company).

The research hypotheses verified in this study are as follows:

$\mathrm{H} 1$ : the business strategies of contemporary enterprises take into account the growing role of intellectual capital, which is reflected in the emphasis put on the development of individual IC subsystems;

$\mathrm{H} 2$ : the development of IC subsystems is based on the activation of international corporate transfers of human capital;

H3: the strategies of the development of the Top-TNCs are based on the pillars reflecting the three IC subsystems - they refer to networking, orchestration and coopetition (although they do not always directly use the names of these categories).

For a long time, researchers have indicated the diverse types of relationships as necessary to be included in the concepts of management. They are calling for the influence of interpersonal relations on business relations in organizations to be studied (Reagans, Zuckerman 2001, pp. 502-517; Kourtit, Nijkamp, van Vught 2014, pp. 235-257), both internally (employees, managers) and externally (suppliers, subcontractors, clients, service institutions, education and administration units). The relations with the highest potential are the ones based on the deeply rooted institutional models, understood as value systems, as well as civilizational and cultural norms. This statement is of crucial importance in the debates on human capital permeating all layers of IC in organizations.

The main purpose of the article is to show the direction of changes in the strategies of TNCs which result from the challenges created by the growing role of IC and the special place of $\mathrm{HC}$ in modern international business. The subject of the study was a group of TNCs classified in the World Investment Report (WIR) The ranking of TNCs in sectors took place with the use of multidimensional statistical analysis (WAS) via the method of linear ordering in accordance with the constructed meter of the creation of added value. The next step included conducting in-depth studies for the three leaders of each sector - the analysis of the pillars of development strategies. By juxtaposing the results of the analyses for the leaders of all sectors on the basis of the GTM, the key indicators of the development of modern corporations were determined based on IC.

The first step of the research involved all 252 TNCs classified in the "Top 100 non-financial TNCs", in the WIR in 1990-2013. The TNCs were divided into sectors. In the second step, on the basis of the value on the meter of the creation of added value for 
2000-2010, the leaders of the individual sectors were chosen. The meter encompassed the values of parameters including all layers of the capital of organizations (Rosińska-Bukowska 2017, pp. 143-157).

The element which reflected the state of the economic capital of an enterprise was the return on equity (ROE), which combines elements which describe the production and sales zone as well as the financial zone. The return on equity (ROE) takes into account the influence of the operational capital of three important factors on profitability - operational effectiveness, the expressed return on sales as well as the effective use of purchased assets and financial leverage. The following indexes reflect the state of intellectual capital:

- the percentage of non-material assets in creating sales value $[(\mathrm{MV}-\mathrm{SE}) / \mathrm{S}]^{1}-$ the influence on the sale of so-called soft stimulants of competitiveness, including the coopetition skill; the attempt at quantifying the hidden factors of the growth of the competitive potential thanks to intellectual capital (Marr, Roos 2005, pp. 28-41);

- the costs of research and development per employee $[(\mathrm{R} \& \mathrm{D}) / \mathrm{E}]^{2}$ - the technological advancement of the production system as compared with the competition, the ability to create new norms and added value;

- the indexes of the internationalization of assets [AVA / A] and employment [EA / E $]^{3}$ - the internationalization of the organizational system; the ability to draw on the multicultural potential of human capital, the arbitrage skills which come from the ability to invest assets abroad, the skilful following of trends, including the movements of the competition as well as the ability of the system to combine competition and cooperation and build creative international teams have been emphasized.

The following step involved studying the key pillars of the development strategies for the leaders of each industrial sector (three TNCs per sector) by analyzing the annual reports of individual corporations. The descriptions of strategies in the annual reports of individual TNCs were analyzed, paying special attention to the significance of individual IC subsystems (INNC, ORGC, INSC) in achieving the developmental targets. The in-depth analyses of the strategic concepts involved studying via the Social Network Analysis method on three levels (Stępka, Subda 2009): the micro-level analysis of a given TNC-leader and its connection system, the number of clients, and its position in the network; the meso-level analysis of groups possessing a given type of resource and which have other common qualities and which cooperate with the TNC; macro-level analysis -identifying the whole structure of the network surrounding the given TNC (nature, methods and forms of cooperation, channels of communication and the exchange of resources).

1 MV - market value; SE - shareholders' equity; S - sales.

2 R\&D - research and development; $E$ - employee/total employment.

3 AVA - assets value abroad -; A - total assets; EA -employment abroad; E - total employment. 
Then, the research results for the three TNC-leaders in each sector were juxtaposed with the base categories - the equivalents of individual layers of intellectual capital: coopetition, networking, orchestration. The degree of fulfillment of individual requirements was assessed according to the adopted scale. The pillars indicated referred to the three layers of intellectual capital:

- networking - as the rules of the organization (ORGC); the implementation of the strategy of networking internationalization based on an unconventional approach which takes into account the social context;

- orchestration - as a model of creation and increasing the efficiency of innovation (INNC) thanks to the use of regulation theory (Pedersen, Venzin, Devinney, Tihanyi 2014) as an innovative form of managing a global multi-level network; the use of all possible types of creating value: market, modular, relational, captive and hierarchy;

- coopetition - as a concept of building relations with a multi-cultural institutional environment (INSC) by combining competition with cooperation, benchmarking, and isomorphism.

The juxtaposition of the results of the analyses for the leaders of all sectors, on the basis of GTM, has identified the key indicators of the development of modern corporations based on IC. Table 1 presents the synthetic juxtaposition of the research results. The results were combined for the TNCs which represent a single sector. The research regarding IC subsystems was qualitative. An important element of the study was the assessment of the influence of ICTs of human capital (the role of HC) on the development of individual IC subsystems of a given TNC on the basis of the enumerated criteria.

On the basis of the research, it has been determined that among the greatest TNCs there is a great similarity of development priorities. It was based on the strength of the economic capital (growth of assets, profitability indexes - financial capital [FC]; the growth of structures for the acquirement of local resources - market capital [MC]), however, currently, the development of intellectual capital is of crucial importance. Individual IC subsystems were assessed on the basis of the following parameters:

- INNC - multi-center R\&D systems; the diversification of the types of chains of value creation; management innovations based on the implementation of the regulatory model;

- ORGC - reorganization of the structures of the global system, including at the internationalization level; the creation of a multi-level network based on ownership links (OL), strategic connections (SC) and cooperation relations (CR); diversification and expansion of the brand portfolio, including large coverage of the market, the role of the leader;

- INSC - development of the network of institutional relations; the diversification of the circle of stakeholders; cooperation with direct competition. 
Human Capital and Intellectual Capital in Modern International Business...

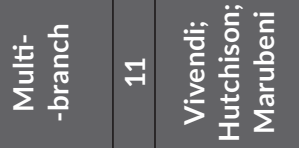

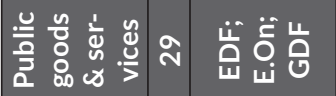

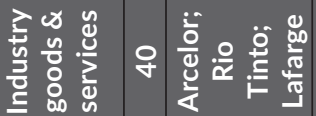

言器

들

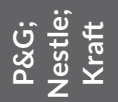

$\begin{array}{llll}+ & + & + \\ + & + & +\end{array}$

\begin{tabular}{lllllll|lll}
+ & + & + & & + & + & & + & + \\
+ & + & + & + & + & + & + & + & + & + \\
+ & + & + & + & + & + & & +
\end{tabular}

$\begin{array}{llll}+ & + & + \\ + & + & + \\ +\end{array}$

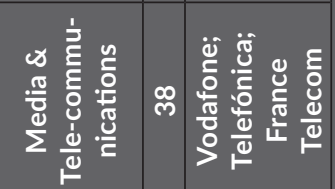

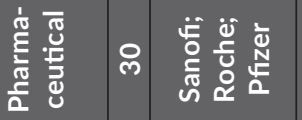

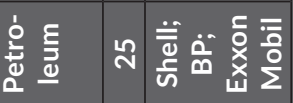

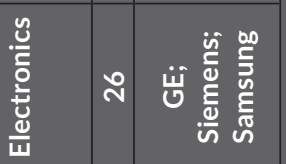

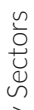

象害

$\begin{array}{llllllllllll}+ & + & + & + & + & & + & + & + & + & & + \\ + & + & + & + & + & + & + & + & + & + & + & +\end{array}$

$+++$

thent

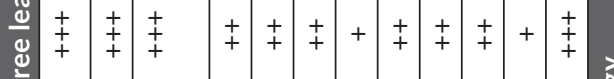

$\begin{array}{llll}+ & + & + \\ + & + & + \\ + & +\end{array}$

\section{t)}

$++++t_{+}+t_{+}+t_{+}+t_{+}$

$++$

ลิ

ฯ

บั)

$\stackrel{\mathscr{Q}}{\simeq}$

$\overleftarrow{0}$

홀

$\frac{\sqrt{n}}{\frac{\pi}{\circ}}$

혼

这

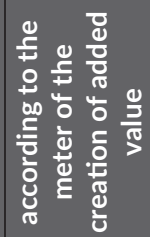

ํㅡ를

U

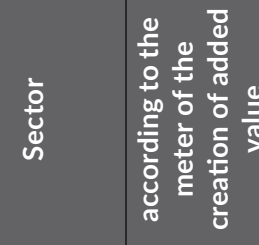

荡

岁

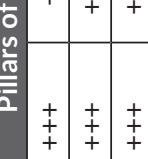

흥

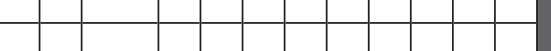

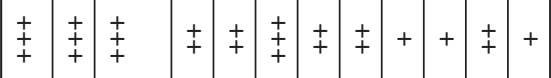

$\begin{array}{lll}+ & + & + \\ + & + & + \\ + & + & +\end{array}$

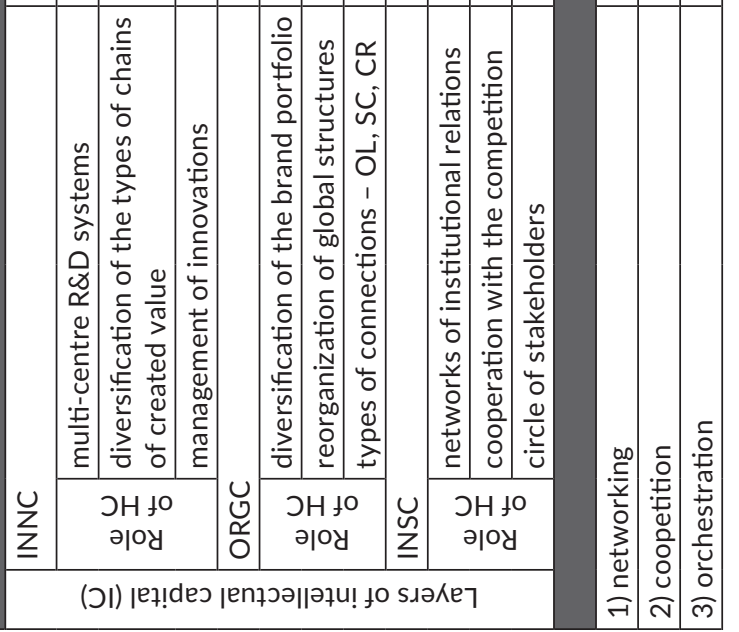

$\frac{\sqrt[0]{0}}{\sqrt[0]{0}}$

西

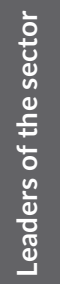

出

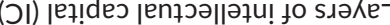


The research has shown that each of the studied TNC-leaders uses an organization and management model based on the development of IC subsystems. As a result of the evolution of business concepts, the TNC-leaders have made some changes to the system of global structures and modifications to the brand portfolio, and they have established various types of cooperation with their competition, etc. This is the result of the Top-TNCs' adjustments to the ongoing changes. All the studied TNCs show changes that take into account the pressure put on the growing role of IC in creating added value. The creation of systems that meet these challenges required, among other things, getting various types of specialists with unique competencies as well as ordinary employees from other cultures, foreign countries, etc., involved in the structures. This, in turn, led to the modification of the pillars of strategy (which was visible during the retrospective analyses of the reports provided by the individual TNCs).

It was confirmed that this group of TNC-leaders bases its developmental strategies on three pillars: networking, coopetition and orchestration, which corresponds with the subsystems of IC, whose activators are the international transfers of human capital in various forms. The most frequently enumerated effects of transfers are: management development (building an international personnel, creating a network of interpersonal connections and relations, broadening the intercultural experience of the corporation; organizing and controlling local operations and coordinating in the GBN of a given corporation; and training the local personnel in order to adapt to the corporation's business model by transferring knowledge, technological and organizational skills, including the shaping of attitudes in conformity with the model of the corporation's organizational culture (building a corporate identity). In this context, the most important effect of the ICTs of HC is the multi-faceted flow of knowledge, experience and competencies within the proper organizational culture of a given corporation (Harzing, Christensen 2004; Myloni, Harzing, Mirza 2004, pp. 518-534). It means that $\mathrm{HC}$ does indeed fulfill the function of the accelerator of the three subsystems of a given corporation's IC.

However, it should be emphasized that the degree to which the requirements of individual categories - networking, orchestration and coopetition - are met differs among the subjects of the study (also as a result the sectors). It is the result of, among other things, the diversity of the starting base - the economic capital - and, for example, the time needed to shape individual IC subsystems. Additionally, the results of the study are preliminary, since the research involved merely the leaders. Complete verification of the hypotheses put forward requires the continuation of the study on a larger group of subjects and taking into account other classifications (aside from WIR), but also more advanced measuring methods. The next stage of the research is already planned. 


\section{Conclusion}

Modern enterprises, regardless of the sector, business model, management strategy as well as the type of organizational and management structure, are based on intellectual capital. Studying the developmental strategies of the Top-TNCs has shown that the skillful use of IC, the capital in the relations, activated thanks to the permeating function of human capital, is their great merit. The modern model of strategic management that emerges is based on the pillars reflecting the significance of IC in the development of enterprises.

The studies have shown that although individual TNCs describe the principles of their developmental strategies in various ways, in accordance with the specificity of their work, the nature of these descriptions is similar. The analysis, which used three parameters for each IC subsystem (ORGC, INNC, INSC), has shown that TNCs notice the importance of individual layers. Depending on the sector, the weight of individual subsystems varies. For the TNCs in the automotive, electronics and pharmaceutical sectors, the innovative IC subsystem is the most important. Meanwhile, the organizational IC subsystem is the most crucial in the following sectors: petroleum, media and telecommunications, consumer goods and services as well as public goods and services. The significance of the institutional IC subsystem is most appreciated by TNCs in the sectors of telecommunications and the public goods and services sectors as well as the consumer goods and services sector. Corporations in all sectors emphasize the role of HC as a catalyst of knowledge resources at all levels of the organizations' relations. It may be said that the leaders of individual sectors create their developmental models taking into account all the IC subsystems, and the essence in the descriptions of the rules of fulfilling strategic guidelines comes down to three pillars: networking, orchestration and coopetition.

Analyzing the materials collected during the studies made it possible to notice the similarity of the greatest corporations' developmental concepts, which makes it possible to point out that the enumerated developmental pillars are the bases of their dynamic development. It is an effect of the system-situation approach, wherein the growing role of the accelerator of the layers of IC is taken by human capital. Consequently, the contemporary business sees the matter of international transfers of $\mathrm{HC}$ as a requirement in the enterprises' developmental strategies. This indicates the necessity to find methods of exploring this capital. It should be mentioned that $\mathrm{HC}$ has a significant influence on the ability to create new business models that facilitate effectiveness due to the restructuring of the system of relations responsible for the speed with which an organization adapts to the constantly changing market conditions.

Referring to hypotheses verified in this study, the author presents the following conclusions:

H1: Studies have shown that although individual TNCs describe the principles of their business strategies in various ways, the essence of the descriptions always focuses on the growing role of intellectual capital. The studies have shown that all 
Top-TNCs notice the importance of three IC subsystems: organizational, innovation, and institutional. These subsystems (ORGC, INNC, INSC) are described differently in particular corporations using parameters individually selected for the specifics of the entity. The key is, however, that they always describe three leading areas: structure, innovation, and institutional environment.

$\mathrm{H} 2$ : The development of IC subsystems is based on the activation of international corporate transfers of human capital. It was confirmed that the studied group of TNC-leaders bases its developmental strategies on building an international personnel, and creating a network of interpersonal connections and relationships, broadening the intercultural experience of the corporation. The most important aspect is training the local personnel in order to adapt to the corporation's business model by transferring knowledge and technological and organizational skills, including the shaping of attitudes in conformity with the corporation's identity.

H3: The pillars of development written in strategies of the most powerful transnational corporations are essentially consistent (though not always identically named), and can be defined as networking, orchestration, and coopetition. Networking means building a multi-level global network based on ownership (proprietary) and strategic and cooperative connections in terms of both economic and intellectual capital. Orchestration is implementing the principles of the regulatory model, enabling individual members of the system to achieve the set goals on the basis of diverse types of organizational and management structures, and appropriately selected brand, distribution and resource management strategies. Additionally, it is the implementation of a sense of coherence based on innovation, sustainable development and the creative character of diversity. Coopetition means the ability to combine competition and cooperation in order to create value added to the constantly growing standard as a result of the internal interactions of all stakeholders.

In conclusion, it can be considered that the hypotheses in the study have been verified. The business strategies of contemporary enterprises take into account the growing role of IC, which is reflected in the emphasis put on the development of individual IC subsystems, based on the activation of ICTs of HC. The strategies of the development of the most powerful transnational corporations are based on three pillars corresponding with the three IC subsystems - they refer to networking, orchestration and coopetition (although not necessarily referring to them directly).

\section{References}

Andelin, M., Karhu, J., Junnila, S. (2015), Creating Shared Value in a Construction Project - a Case Study, "Procedia Economics\&Finance", Vol. 21, Elsevier Science B.V, Nordic Conference on Construction-Economics-and-Organization, Tampere, Finland.

Bonache, J., Brewster, C. (2001), Knowledge Transfer and the Management of Expatriation, "Thunderbird International Business Review”, Vol. 43 (1), Thunderbird School 
of Global Management, John Wiley \& Sons, Inc., https://onlinelibrary.wiley.com/ doi/epdf (accessed: 11.05.2018).

Bontis, N. (2001), Assessing Knowledge Assets: A Review of the Models used to Measure Intellectual Capital, "International Journal of Management Reviews”, Vol. 3 (1), British Academy of Management, John Wiley \& Sons, Inc..

Bounfour, A. (2003), The IC-dVAL Approach, "Journal of Intellectual Capital", Vol. 4, MCB UP Ltd, Emerald Publishing.

Brennan, N., Connell, B. (2000), Intellectual Capital: Current Issues And Policy Implications, "Journal of Intellectual Capital", Vol. 1 (3), MCB UP Ltd, Emerald Publishing.

Choong, K. (2008), Intellectual Capital: Definitions, Categorization and Reporting Models, "Journal of Intellectual Capital” Vol. 9 (4), Emerald Publishing, .

Coorens, A. (2013), Increasing the Effectiveness of International Assignments: Aligning them with the Goals of the Organization and Assignees, http://essay.utwente. nl/64098.pdf (accessed: 13.07.2018).

Coviello, N.E., Jones, M.V., McDougall-Covin, P. (2014), Is International Entrepreneurship research a viable spin-off from its parent disciplines? [in:] Fayolle, A., Riot, P. (ed.), Institutionalization of Entrepreneurship: Hopes and Pitfalls for Entrepreneurship Research, Routledge.

Dhanaraj, C., Parkhe, A. (2006), Orchestrating Innovation Networks, "Academy of Management Review", Vol. 31 (3).

D"Costa, A.P., (2006), The International Mobility of Technical Talent. Trends and Development Implication, Research Paper, United Nations University, No. 143, https:// www.wider.unu.edu/ sites/default/files/rp2006-143.pdf (accessed: 19.07.2018).

Dowling, P.J., Festing, M., Engle, A.D., (2013), International Human Resource Management, Cengage Learning EMEA, Andover.

Global Mobility Trends Survey Report 2015, Brookfield Global Relocation Services. http://globalmobilitytrends.brookfieldgrs.com (accessed: 11.06.2018).

Gorynia, M., Dzikowska, M. (2012), Teoretyczne aspekty konkurencyjności przedsiębiorstwa - w kierunku koncepcji eklektycznej? "Gospodarka Narodowa”, Vol. 4, Kolegium Analiz Ekonomicznych Szkoły Głównej Handlowej w Warszawie, Warszawa.

Hagen, B., Denicolai, S., Zuchella, A. (2014), International entrepreneurship at the crossroads between innovation and internationalization, "Journal of International Entrepreneurship”, Vol. 12 (2), Springer Science \& Business Media, New York.

Håkansson, H., Snehota, I. (1995), Developing Relationship in Business Networks, Routledge, London.

Harzing, A-W. (2001), Of Bears, Bumble-bees, and Spiders: The Role of Expatriates in Controlling Foreign Subsidiaries, "Journal of World Business", Elsevier, Vol. 36 (4), https://harzing.com/download/spiders.pdf (accessed: 11.06.2018).

Harzin A-W., Christense C. (2004), Expatriate Failure: Time to Abandon the Concept? “Career Development International”, Vol. 9 (7), Emerald Group Publishing Limited.

Harzin A-W., Reiche, S.B. (2009), International Assignment, [in:] Harzing, A-W. Pinnington A. (eds.) International Human Resource Management, Sage Publications, London.

Hodgson, G.M., Knudsen, T. (2006), The Nature and Units of Social Selection, "Journal of Evolutionary Economics", Vol. 16 (5). 
Klaila, D. (2000), Using Intellectual Assets as a Success Strategy, "Journal of Intellectual Capital", Vol. 1 (1), Emerald Publishing.

Kostova, K., Roth, T.K. (2003), Social Capital in Multinational Corporations and a micro-macro Model of its Formation, “Academy of Management Review”, Vol. 28, Academy of Management Briarcliff Manor, New York, USA.

Kourtit, K., Nijkamp, P., van Vught, F. (2014), Clusters of Supernova Stars in knowledge-based Spaces: Value Creation through Cooperation, "International Journal of Global Environmental Issues", Vol. 13 (2-4), Inderscience Publishers.

Massey, D.S. Arango, J., Hugo, G., Kouaouci, A., Pellegrino, A., Taylor, J.E. (2005), World in Motion: Understanding International Migration at the End of the Millennium, Oxford University Press.

McCutcheon, G. (2008), EVVICAE, a valuation model for intellectual asset-rich businesses, "Measuring Business Excellence", Vol. 12 (2), Emerald Publishing.

McDougall-Covin, P., Jones, M.V., Serapio, M.G. (2014), High-Potential Concepts, Phenomena, and Theories for the Advancement of Entrepreneurship Research, "Entrepreneurship Theory and Practice", Vol. 38 (1), Wiley.

Myloni, B., Harzing, A-W., Mirza, H. (2004), Host Country Specific Factors and the Transfer of Human Resources Management Practices in Multinational Companies, "International Journal of Manpower", Vol. 25 (6), Emerald Publishing.

Lyles, M.A., Salk, J.E. (1996), Knowledge Acquisition from Foreign Parent in International Joint-ventures: An Empirical Examination in the Hungarian Context, "Journal of International Business Studies”, Vol. 27 (5), Palgrave Macmillan.

Petty, R., Guthrie, J. (2000), Intellectual Capital Literature Review. Measurement, Reporting and Management, "Journal of Intellectual Capital", Vol. 1 (2), Emerald Publishing.

Pedersen, T., Venzin, M., Devinney, T.M., Tihanyi, L. (2014), Orchestration of the Global Network Organization, "Advances in International Management", Vol. 27, Emerald Insight.

Pike, S., Rylander, A., Roos, G. (2001), Intellectual Capital Management and Disclosure, Paper presented at the $4^{\text {th }}$ World Congress on Intellectual Capital, McMaster University, Hamilton, Ontario, Canada.

Reagans, R., Zuckerman, E.W. (2001), Networks, Diversity and Productivity: The Social Capital of Corporate R\&D Teams, "Organization Science”, Vol. 12 (4), Informs PubsOnLine.

Reiche, S., Kraimer, M., Harzing, A.W. (2008), Inpatriates as Agents of Cross-Unit Knowledge Flows in Multinational Corporations, http://www.harzing.com/download/inpatsbc.pdf (accessed 14.07.2018).

Rosińska-Bukowska, M. (2012), Rozwój globalnych sieci biznesowych jako strategia konkurencyjna korporacji transnarodowych, Publishing House of University of Lodz.

Rosińska-Bukowska, M. (2017), Strategic changes in transnational corporation as an adjustment to the challenges of the $21^{\text {st }}$ Century, "Entrepreneurial Business and Economics Review”, Vol. 5 (2), Publishing House of Cracow University of Economics. 
Ross, G., Ross, J. (1997), Measuring your Company's Intellectual Performance, "Long Range Planning” June, https://www.researchgate.net/publication/222479978 (accessed: 12.05 .2018$)$.

Sarvary, M. (1999), Knowledge Management and Competition in the Consulting Industry, "California Management Review", Vol. 41 (2), SAGE Journals, BerkeleyHaas.

Saxenian, A.L. (2006), International Mobility of Engineers and the Rise of Entrepreneurship in the Periphery, WIDER Research Paper 2006/142, UNU-WIDER, Helsinki.

Skyrme, D.J. (1999), Knowledge Networking. Creating the Collaborative Enterprise, Butterworth Heinemann, Oxford.

Stahle, P., Stahle, S, Aho, S. (2011), Value Added Intellectual Coefficient (VAIC): A Critical Analysis, "Journal of Intellectual Capital", Vol. 12 (4), Emerald Publishing.

Stewart, T.A. (2001), The Wealth of Knowledge. Intellectual Capital and the Twenty-First Century Organization, Nicholas Brealey Publishing, London.

Stępka, P., Subda, K. (2009), Wykorzystanie analizy sieci społecznych (SNA) do budowy organizacji opartej na wiedzy, "E-mentor”, No. 1 (28), www.e-mentor.edu.pl/artykul/ index/numer/28/id/618 (accessed: 23.07.2018).

Sveiby, K.E. (2015), Methods for Measuring Intellectual Capital, www.sveiby.com (accessed: 23.07.2018).

Thomson, G., Frances, J., Levacic, R., Mitchell, J. (1991), Markets, Hierarchies and Networks: The Co-ordination of Social Life, Sage Publications, London.

Vahlne, J.E., Ivarsson, I. (2014), The globalization of Swedish MNEs: Empirical evidence and theoretical explanations, "Journal of International Business Studies", Vol. 45 (3), Palgrave Journals, University of Gothenburg.

Viedma, J.M. (2001), ICBS Intellectual Capital Benchmarking System, "Journal of Intellectual Capital", No. 2, Emerald Publishing.

Wach, K. (2015), Incremental versus Rapid Internationalisation of Firms: Results of Exploratory Investigation from Poland, "Entrepreneurial Business and Economics Review", Vol. 3 (4), Publishing House of Cracow University of Economics.

Wall, A., Kirk, R., Martin, G. (2004), Intellectual Capital. Measuring the Immeasurable?, CIMA Publishing Elsevier, Oxford.

Zucchella, A., Scabini, P. (2007), International Entrepreneurship - Theoretical Foundations and Practice, Palgrave Macmillan, New York. 


\section{Streszczenie}

\section{Kapitał ludzki i kapitał intelektualny we współczesnym biznesie międzynarodowym. Na podstawie badań strategii korporacji transnarodowych}

Główny celem artykułu jest ukazanie kierunków zmian w strategiach najpotężniejszych korporacji transnarodowych w efekcie wyzwań związanych z rosnącą rolą kapitału intelektualnego i szczególnym miejscem kapitału ludzkiego we współczesnym biznesie międzynarodowym. Dodatkowo bazując na Grounded Theory Methodology wskazanie kluczowych filarów strategii pozwalających przedsiębiorstwom efektywnie sprostać nowym wyzwaniom. Opracowanie zostało podzielone na trzy części. W części pierwszej omówiono najważniejsze kwestie teoretyczne dotyczące miejsca kapitału intelektualnego i kapitału ludzkiego w strategiach współczesnych przedsiębiorstw. W drugiej części scharakteryzowano nowe trendy w międzynarodowych transferach kapitału ludzkiego. W kolejnej części, na podstawie przeprowadzonych badań, omówiono wpływ zachodzących zmian na system organizacyjno-zarządczy przedsiębiorstw - na przykładzie najpotężniejszych korporacji transnarodowych. Badania wykazały, że wszystkie najpotężniejsze korporacje transnarodowe zauważają rosnącą rolę kapitału intelektualnego we współczesnym biznesie. Podstawą strategii korporacji jest nacisk na rozwój podsystemów kapitału intelektualnego, odnoszący się do aktywizacji międzynarodowych transferów kapitału ludzkiego. W konsekwencji strategie rozwoju najpotężniejszych korporacji transnarodowych oparte są na trzech filarach: sieciowości, orkiestracji, kooperencji i bazują na trzech podsystemach kapitatu intelektualnego: kapitale organizacyjnym, innowacyjnym, instytucjonalnym.

Słowa kluczowe: kapitał ludzki, kapitał intelektualny, korporacje transnarodowe, biznes międzynarodowy 